\title{
PEMANFAATAN SISTEM INFORMASI ARSIP DI DESA BILANGAN KECAMATAN BATANG-BATANG
}

\author{
Imam Hidayat ${ }^{1}$, Ach. Andiriyanto ${ }^{2}$, Imam Darul Firmansyah ${ }^{3}$ \\ ${ }^{1,2)}$ Fakultas Ilmu Sosial dan Ilmu Politik Universitas Wiraraja \\ ${ }^{3)}$ Fakultas Ekonomi dan Bisnis Universitas Wiraraja \\ Email: ${ }^{1)}$ imamhidayat@wiraraja.ac.id, ${ }^{2)}$ aryauri@gmail.com, ${ }^{3)}$ imamdaru@wiraraja.ac.id
}

\begin{abstract}
ABSTRAK
Pemanfaatan Sistem Informasi Arsip Desa merupakan trobosan daninovasi terbaru yangdirekomendasikan kepada aparatur desa di Desa Bilangan Kecamatan Batang-batang Kabupaten Sumenep, sebagai solusi yang tepat untuk menata informasi arsip desa secara terbuka, efektif dan memberikan pelayanan yang berkualitas bagi masyarakat dan lembaga lainnya. Peluang era digitalisasi harus mampu memberikan dampak signifikan bagi kemajuan pelayanan desa, disamping aparatur desa yang mampu menjalankan komputer maka kesempatan ini menjadi peluang untuk dijalankannya Sistem Informasi Arsip Desa. Proses pelayanan selama ini terkesan tidak efektif dan efesien untuk itu perlu adanya sistem atau aplikasi yang mampu memberikan solusi atas permasalahn tersebut, karena untuk di kantor desa sendiri komputer yang ada belum termanfaatkan dengan baik. Untuk itu perlu adanya pembinaan secara intens dengan memberikan pengetahuan dibidang pengelolaan informasi dan arsip desasehingga aparatur desa menyadari akan pentingnya pengelolaan informasi arsip desa yang dijalankan lebih sistematis dan terjaga secara aman semua informasi terkait desa.Sistem Informasi Arsip Desa yang berbasis komputer ini memberikan peluang yang signifikan bagi kualitas pelayanan kantor desa, sehingga pembinaan atau pelatihan ini penting untuk diadakan sebagai jawaban dari dunia digitalisasi yang semua unsur kepentingan informasi sudah bisa diakses ari komputerisasi. Metode kegaiatan pengabdian ini dengan melakukan proses pendampingan dan pelatihan kepada aparatur desa dengan memberikan materi cara pengarsipan secara digital tidak lagi dengan menggunakan proses input manual. Adapaun dari hasil kegiatan pengabdian ini membiasakan aparatur desa menggunakan sistem yang kami buat agar lebih efektif dan efesien dalam memberikan pelayanan kepada masyarakat desa bilangan dan yang membutuhkan.
\end{abstract}

Kata kunci: Pemanfaatan Tekhnologi, Sistem Informasi, Arsip Surat

\section{PENDAHULUAN}

Dalam perkembangan zaman sekarang, teknologi komunikasi berkembang begitu pesat, banyak bermunculnya berbagai alat telekomunikasi atau perhubungan yang canggih, seperti: telepon seluler, televisi, radio, telegram, faksimili dan lain sebagainya (Suryadi, 2019). Era digitalisasi memberikan peluang tinggi bagi pemerintah untuk terus memberikan pelayanan berkualitas bagi kepentingan publik, semakin cepat teratasi kebutuhan masyarakat meruapakan salah indikator keberhasilan penyelenggaraan pemerintahan yang baik.

$$
\text { Bonus era digitalisasi mampu }
$$
merubah tata kelola pelayanan yang pada semula terkesan lelet berubah menjadi 
sangat cepat dengan menyajikan ke efektivan bagi penyelenggara pelayanan.

Pemerintah sendiri dituntut untuk lebih inovatif dalam penyelenggaraan pelayanan dengan mampu menciptakan sistem melalui komputerirasi dalam mebantu kecapatan pelayanan yang bermanfaat bagi semua lapisan masyarakat.Untuk itu diperlukan suatu Sistem Informasi yang terkomputerisasi yang mampu mengatasi kendala dan masalah yang ada dalam desa (Rusmayanti, 2014).

Disamping itu dengan penerapan ini mampu mengatasi potensi keberpihakan terhadap kepentingan sebagian kelompok masyarakat, transparan dan akuntabilitas salah satu dampak dari kemajuan digitalisasi.

Peran pemerintah untuk terus memberikan segala akses informasi yang cepat dan tepat bertujuan memberikan respon yang positif bagi semua urusan permasalahan dari masyarakat.Salah satu peran penting bagi kemajuan bangsa adalah peran aktifnya aparatur desa untuk memberikan kualitas pelayanan yang menyentuh terhadap semu keperluan masyarakat dan memudahkah aparatur desa dalam proses pengelolaan pelayanan pemerintah.Perkembangan teknologi bukan hanya dimanfaatkan oleh masyarakat kota namun juga oleh masyarakat pedesaan.
Masyarakat desa sudah tidak asing lagi dengan penggunaan telepon seluler, internet dan lain-lain. Walaupun belum semua wilayah di Indonesia dapat memanfaatkan teknologi informasi namun dengan seiring waktu berjalan niscaya teknologi informasi akan sangat cepat berkembang hingga pelosok wilayah Indonesia (Sulistyowati, 2013).

Kemampuan aparatur desa dalam menemukan pelayanan yang berbasis digitalisasi tergolong masih lemah, masih jarang ditemui kegiatan pelayanan yang berbasis digitalisasi di desa.Maka apatur desa perlu mencarikan solusi yang tepat untuk menemukan sistem informasi arsip di Desa. Di era otonomi daerah, desa merupakan bagian yang sangat penting dalam menentukan keberhasilan pembangunan dan bersetuhan langsung dengan masyarakat terutama dalam pelayanan publik. Masalah yang timbul dan dihadapi adalah minimnya tingkat ketrampilan aparatur desa dengan tuntutan masyarakat yang lebih dinamis serta sistem pengelolaan arsip masih bersifat konvensional memicu resiko tinggi.

Informasi dan pengarsipan merupakan salah satu hal penting dalam urusan pelayanan desa, jika hal ini bisa diatasi dengan baik oleh aparatur desa denga inovasi perubahan ke arah lebih maju tentu akan sangat membantu terhadap 
segala urusan kepentingan masyarakat di Desa.Sistem informasi kependudukan di maksudkan untuk meningkatkan efisiensi dalam hal pelayanan masyarakat (Rozi, 2017).

Desa bilangan merupakan desa yang terdapat di kecamatan batang-batang, seperti hal dengan di desa-desa lain, desa ini juga memiliki pemerintah desa yang mempunyai tugas dan tanggung jawab melayani segala urusan kebutuhan masyarakat salah satunya adalah informasi mengenai program desa serta tata kelola kearsipan yang menjadi aktifitas pekerjaan sehari-hari dari pemerintah desa bilangan.

Fenomina yang ditemui di lapangan pemerintah desa bilangan masih rumit soal informasi kearsipan, pelayanan masih tergolong lelet dan kadang juga terdapat kendala soal data desa sehingga hal uni tentu berpengaruh terhadap kualitas pelayanan.Perubahan dan dinamika masyarakat tertutama dalam bidang arsip surat dibutuhkan informasi yang akurat, cepat, dan tepat (Saifudin 2019)

Penulis mencoba memberikan solusi permasalahan diatas, dengan membuatkan program alplikasi dengan sistem informasi arsip desa guna memberikan kemudahan pelayana aparatur desa dan memberikan kepuasan pelayanan yang menyentuh terhadap semua lapisan masyarakat dengan judul pengabdian ini "pemanfaatan sistem informasi arsip di Desa Bilangan Kecamatan Batang-Batang”.

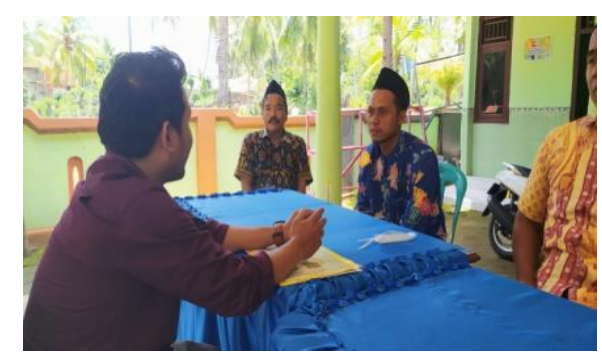

Gambar 1: Wawancara dengan aparatur desa berkenaan dengan masalah-masalah administrasi desa dan kesulitas input arsip desa

\section{METODE}

Metode pelaksanaan prorgram kemitraan ini berupa pelatihan dan pendampingan. Pelatihan akan dilaksanakan di lokasi mitra yaitu Desa Bilangan Kecamatan Batang-batang Kabupaten Sumenep yang berjarak $27 \mathrm{~km}$ dari Universitas Wiraraja Sumenep. Pelatihan pengoprasian sistem informasi arsip desa ini akan diberikan oleh ketua tim Program Kemitraan Masyarakat dan Anggota 1 memiliki tugas sebagai pengelola lebih detail mengenai cara menjalankan tata teknis sistem informasi dan kearsipan desa serta menganalis tindak lanjut usaha dilapangan, sedangkan anggota 2 yang memiliki keahlian dalam ilmu tekhnoogi sistem informasi arsip desa. Peserta dalam pelatihan ini adalah aparatur desa sebanyak 20 Orang. Pelatihan akan dilaksanakan di lokasi mitra 
yaitu Desa Bilangan Kecamatan Batangbatang Kabupaten Sumenep.

Kegiatan pelatihan terdiri dari proses penyampaian materi dalam betuk ceramah, diskusi serta praktek menjalankan sistem informasi arsip desa. Melalui tahapan kegiatan ini maka akan tercipta keterampilan baru pada mitra yang mampu merubah informasi arsip desa yang sebelumya dilakukan dengan input manual namun dengan sistem ini aparatur desa mampu merubahnya melalui sistem komputerisasi yang cepat dan aman. Selain kegiatan pelatihan tim Program Kemitraan Masyarakat juga akan melakukan pendampingan, pelatihan serta evaluasi agar sistem ini selalu bisa diapakai dimasa yang akan datang. Bentuk pendampingan pelatihan ini berupa kunjungan tim Program Kemitraan Masyarakat ke lokasi mitra untuk mengevaluasi jalannya tata kelola penyediaan sistem informasi arsip desa. Kegiatan pelatihan maupun kunjungan untuk evaluasi akan dilaksanakan pada hari sabtu dan minggu.

\section{HASIL DAN PEMBAHASAN}

Hasil dan Pembahasan berisi satu kesatuan antara hasil dan pembahasan kegiatan yang dilakukan. Hasil dan Pembahasan dapat terdiri dari beberapa sub- bahasan yang ditulis secara sistematis.
Untuk mengetahui keterlaksanaan program pengabdian masyarakat, perlu diadakan adanya evaluasi terkait program yang telah direncanakan. Terutama respon dari apartur desa pemerintah desa bilangan terkait pelatihan dan pembinaan system informasi pengarsipan secara digitalisasi di berikan oleh tim pengabdian masyarakat Universitas Wiraraja Sumenep terhadap aparatur pemerintah Desa Bilangan, Kecamatan Batang-Batang.

Pelaksanaan kegiatan pengabdian juga tidak lepas dari berbagai kendala yang dihadapi oleh tim, seperti halnya rendahnya tingkat pengetahuan mitra terhadap dunia tekhnologi yang semakin canggih. Adanya kendala yang disebutkan tersebut perlu menjadi perhatian apabila dilain waktu dan kesempatan dilaksanakan pengabdian masyarakat kembali di masa yang akan datang untuk lebih memperhatikan pengayoman yang total terhadap sasaran pengabdian.

Peserta pengabdian masyarakat adalah Aparatur Pemerintahan Desa Bilangan, dimana awal sosialisasi tim pengabdian masyarakat melakukan kerjasama dan koordinasi dengan Kepala Desa Bilangan. Kerjasama dilakukan sebagai langkah pertama untuk lebih dekat dengan aparatur Desa Bilangan dan mengetahui problem yang dihadapi apartur pemerintah desa bilanagan ketika 
menganggap sepeleh terhadap pengarsipan melalui tekhnologi yang berguna bagi pelayanan di desa bilangan. Dari kerjasama tersebut dalam pertemuan aparatur pemerintah desa bilangan dengan melakukan perkenalan terkait tujuan dari pengabdian masyarakat. Pertemuan dengan pelaku usaha gula merah bisa dilihat pada gambar sebagai berikut.

Interakasi dengan aparatur pemerintah desa bilangan mengenai pelatihan sistem informasi arsip desa di era globalisasi saat ini, sehingga di temukan beberapa pokok masalah yang menjadi alasan dari aparatur desa bilangan yang enggan untuk beradaptasi pada era globalisasi. Beberapa problem tersebut adalah;

1. Faktor pengetahun, Aparatur Desa Pemerintah Desa Biangan pada umumnya masih belum mengenal secara detail tentang tekhnologi era modern dengan segala fasilitas pelayanan yang semakin cepat da tepat.

2. Faktor budaya dan mindset aparatur pemerintah desa bilangan, faktor ini masih melekat erat dalam kehidupan aparatur terutama dalam pengoprasian arsip secara digitalisasi. Hal ini menjadi faktor yang paling banyak menjadi alasan para apartur yang hanya pasrah dengan situasi yang terjadi tanpa mau berusaha untuk lebih mengetahui mengoprasikan komputer sebagai salah satu input arsip desa yang sangat berguna bagi efektifitas pelayanan administrasi desa.

Dengan mengetahui permasalahan aparatur desa bilangan, tim pengabdian masyarakat melakukan sosilisasi dengan memberikan pelatihan dan pembinaan dasar cara input arsip desa ke komputer dan dilanjutkan pada sistem informasi tekhnologi.

Karena pengabdian masyarakat ini bersifat pelatihan dan pembinaan, maka alat perantara yang digunakan selama melakukan kegiatan adalah modul petunui teknis, kompuetr dan contoh arsip surat.Tape recorder digunakan untuk merekam interaksi tanya jawab yang dilakukan tim pengabdian dengan aparatur desa Bilangan, Laptop digunakan untuk memperkenalkan beberapa teknis kegiatan pengarsipan secara digitalisasi, sedangka buku tulis dan pulpen berfungsi untuk mencatat hal-hal apa yang menjadi point penting selama interkasi.

Pelaksnaan pengabdian kepada masyarakat ini merupakan kelanjutan dari pengabdian internal Universitas Wiraraja,

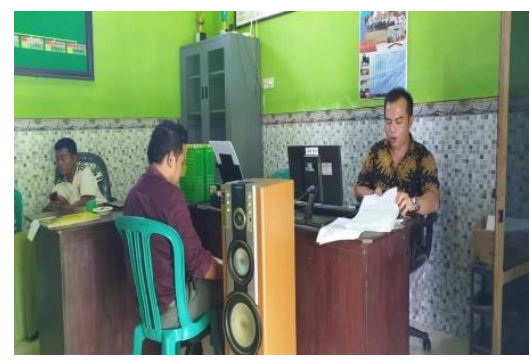


Gambar 2 Pendampingan dan pelatihan input arsip desa

\section{SIMPULAN}

Arsip di Desa Bilangan Kecamatan Batang-batang merupakan solusi yang tepat untuk pelayanan informasi dan kearsipan desa yang efektif berbasis data yang akurat.

\section{DAFTAR PUSTAKA}

Agusta, I. 2002. Metode Evaluasi Program Pemberdayaan. Humaniora Utama Press: Bandung

Suryadi, Ade. Rancang Bangun Sistem Pengelolaan Arsip Surat Berbasis Web Menggunakan MetodeWaterfall (Studi kasus : Kantor Desa Karangrau Banyumas) Fakultas Teknologi Informasi, Universitas Bina Sarana Informatika Jurnal Khatulistiwa Informatika.Vol.VII, No 1 Juni 2019 p-ISSN: 2339-1928 \& e-ISSN: 2579-633X .

Rusmayanti, Atik. Sistem Informasi Pengelolaan Keuangan Pada Desa Ngadirejan. Universitas Surakarta. Journal Speed - Sentra Penelitian Engineering dan Edukasi. Volume 6 No 2 - 2014.

Sulistyowati, Fadjarini. Partisipasi Warga terhadap Sistem Informasi Desa Program Studi Ilmu Komunikasi STPMD "APMD” Yogyakarta. Journal Aspikom (Asosiasi Pendidikan Tinggi Ilmu Komunikasi). Vol 2, No 12013 PISSN:2087-0442 E-ISSN: 25488309.

Rozi, Fahrur. Pengmbangan Websitete dan Sistem Informasi Desa di Kabuapten Tulungagung. JIPI (Jurnal Ilmiah Penelitian dan Pembelajaran
Informatika). Volume 02, Nomor 02, Desember 2017 . E-ISSN : 2540 8984.

Saifudin, dkk. Sistem Informasi Arsip Surat (SINAU) berbasis WEB pada Kantor Desa Karangsalam Kecamatan Baturraden. Evolusi: Jurnal Sains dan Manajemen. Vol 7 No. 2 September 2019 ISSN:23388161 E-ISSN: 2657-0793. 